\title{
Persepsi Mahasiswa terhadap Profil Dosen Menggunakan Analisis Konjoin
}

\author{
Yuliana $^{1 *}$, Eric Kunto Aribowo ${ }^{2}$, Anna Febrianty Setianingtyas ${ }^{3}$ \\ 1,2,3 Universitas Widya Dharma Klaten \\ *email: pakyulikids@unwidha.ac.id \\ (Received: 05-02-2021; Reviewed: 07-02-2021; Accepted: 04-03-2021)
}

\begin{abstract}
Abstrak
Penelitian ini mengungkap persepsi mahasiswa terhadap kompetensi yang dimiliki oleh dosen. Dengan melakukan ekstraksi dari empat kompetensi dosen (pedagogik, profesional, sosial, dan kepribadian) yang dilanjutkan dengan justifikasi dari tim ahli dihasilkan lima profil utama: umpan balik, metode pembelajaran, penguasaan materi, disiplin, dan sikap dosen. Melalui analisis konjoin ditemukan bahwa kombinasi yang paling dipertimbangkan dan dianggap penting oleh mahasiswa, yaitu dosen yang dalam perkuliahannya menggunakan metode pembelajaran yang mutakhir, dosen yang bersikap wajar terhadap mahasiswanya, dosen yang tidak terlalu tinggi tingkat kedisiplinannya, dosen yang selalu memberikan umpan balik, dan dosen yang mampu mengaplikasikan materi. Persepsi dari ciri-ciri dosen inilah yang diinginkan oleh mahasiswa sehingga dapat memberikan pengaruh atau memotivasi semangat belajar.
\end{abstract}

Kata Kunci: Analisis konjoin, kompetensi dosen, persepsi mahasiswa, profil dosen

\section{PENDAHULUAN}

Tak dipungkiri bahwa semakin banyaknya perguruan tinggi swasta (PTS) di Indonesia akan mengundang kompetisi diantara perguruan tinggi swasta dalam memikat minat para calon mahasiswa. Berbagai cara dilakukan PTS untuk memikat minat para calon konsumen dalam hal ini adalah mahasiswa, seperti usaha meningkatkan kualitas pendidikan maupun pelayanan perguruan tinggi. Selama ini, Universitas Widya Dharma sudah melakukan berbagai usaha perbaikan kualitas pendidikan melalui meningkatkan akreditasi program studi maupun PT oleh BANPT, monitoring pembelajaran dosen secara berkala, dan kualitas pelayanan akademik maupun non akademik. Walaupun sudah melakukan usaha-usaha tersebut, jumlah mahasiswa justru tidak mengalami kenaikan dalam tiga tahun terakhir.

Apakah yang menjadi penyebab penurunan minat mahasiswa masih perlu digali. Selama ini, PTS sudah melakukan sosialisasi kepada masyarakat mengenai produk dan profilnya. Ironisnya, justru keinginan mahasiswa yang selama ini sudah mengikuti perkuliahan belum tergali secara maksimal. Mahasiswa yang merasakan pelayanan selama perkuliahan justru belum tergali seperti apa pelayanan yang diinginkannya dan kualitas pengajaran seperti apa yang diinginkannya dari dosennya.

Sumber Daya Manusia, khususnya dosen menjadi bagian komponen yang berpengaruh untuk menciptakan sistem pendidikan di samping komponen sarana-prasarana, pembiayaan, dan tata kelola perguruan tinggi yang baik. Sebagai pelaksana teknis operasional di suatu perguruan tinggi, dosen memiliki kontribusi yang penting terhadap berhasil atau tidaknya perguruan tinggi untuk mewujudkan visi, misi, serta tujuan yang telah dicanangkan (Enoh, 2006). Dosen menjadi komponen utama di perguruan tinggi memiliki peranan besar untuk mewujudkan kualitas perguruan tinggi yang menjadi harapannya (Sudiana, 2003). Unsur kualitas dosen telah terbukti memberikan dampak positif terhadap motivasi belajar mahasiswa serta memiliki keterkaitan yang paling kuat 
dibandingkan dengan faktor-faktor lainnya (Pujadi, 2007). Mahasiswa menjadi bagian yang terlibat langsung dengan dosen ketika pembelajaran pastilah mempunyai preferensi tertentu terhadap mutu dosen.

Minat calon mahasiswa untuk meneruskan belajarnya ke tingkat perguruan tinggi terus menurun salah satunya disebabkan karena kepuasan mahasiswa dalam pelayanan juga menurun. Kepuasan mahasiswa yang lama kelamaan makin menurun berakibat pada beberapa perguruan tinggi yang tutup karena kekurangan mahasiswa (Sahyar, 2009). Oleh karena itu, kepuasan pelanggan (dalam konteks ini mahasiswa) menjadi kunci agar suatu perguruan tinggi terus tetap berkembang. Kepuasan mahasiswa dapat ditingkatkan dengan jalan meningkatkan kualitas proses pembelajaran, yang salah satunya dengan meningkatkan kompetensi dosen. Dengan kata lain, dosen memiliki peranan yang besar untuk meningkatkan kepuasan mahasiswa sehingga perguruan tinggi terus berkembang.

Apabila seorang dosen mampu berperan sebagai pembimbing maka dia dapat mempengaruhi kebiasaan individu (mahasiswanya) sewaktu belajar. Semangat belajar mahasiswa menjadi komponen dominan dalam proses belajar sebab mampu mendorong mahasiswa untuk terus bersemangat dalam mencapai hasil belajar yang semakin baik. Pada umumnya, setiap mahasiswa menginginkan hasil sebaik-baiknya sebagai pembuktian kepada orang lain atas kemampuannya dan hasil pencapaian yang telah diperolehnya (Setianingtyas, 2012). Sementara itu, Kottasz (2005) berpendapat bahwa ketidakhadiran mahasiswa dalam mengikuti perkuliahan dikarenakan adanya motivasi yang kurang dalam diri mahasiswa. Mahasiswa mengungkapkan penyebab justru untuk tidak hadir mengikuti perkuliahan, diantaranya (1) mahasiswa cenderung tertekan dengan tugastugas, (2) perkuliahan yang diberikan kurang begitu baik, (3) perkuliahan yang tidak sesuai dengan jadwalnya karena adanya perubahan, dan (4) kualitas materi perkuliahan yang kurang bermutu.

Berdasarkan data dari pernyataan yang diungkapkan di atas, maka peneliti tertarik dalam melakukan penelitian mengenai persepsi mahasiswa terhadap dosennya. Persepsi dosen seperti apakah yang diinginkan mahasiswa terhadapnya sehingga mampu memotivasi mahasiswa selalu untuk terus bersemangat belajar? Persepsi mahasiswa terhadap dosen merupakan hasil penafsiran mengenai kompetensi dosen yang didapatkan dari pengamatan, penilaian, maupun intrepretasi selama proses berinteraksi dengan mahasiswa (Sutriningsih, 2016). Persepsi yang baik terhadap dosen tertentu akan berimbas pada ketertarikan mahasiswa terhadap perkuliahan sehingga dapat mengembangkan perguruan tinggi yang dinaunginya. Sebaliknya, persepsi yang negatif akan menumbuhkan perasaan tidak suka, acuh, takut, maupun tidak termotivasinya dalam mengikuti perkuliahan. Melalui penelitian ini, keinginan dan harapan mahasiswa dapat tereksplorasi. Setelah keinginan mahasiswa tereksplorasi, maka suatu kebijakan yang tepat dapat diambil oleh pimpinan demi meningkatnya minat calon mahasiswa.

\section{Metode}

Responden penelitian ini mencakup mahasiswa dari tujuh belas (17) program studi di lingkungan Perguruan Tinggi Swasta di Klaten. Mahasiswa yang dijadikan responden dengan syarat telah menempuh Pendidikan minimal dua semester sehingga setidaknya telah mengenal baik dosen pengampu mata kuliah masing-masing. Sampel penelitian terdiri dari 270 mahasiswa yang dikumpulkan dengan teknik purpossive random sampling. Melalui metode purpossive random sampling, peneliti mendapatkan informasi yang dibutuhkan dari responden (Wibisono, 2003). Dari 
kartu profil yang telah dibagikan melalui pesan instan Whatsapp terkumpul data yang akan dianalisis.

Dalam menganalisis preferensi mahasiswa mengenai kualitas para dosennya, sekaligus untuk meninjau segmentasinya, peneliti menggunakan analisis konjoin. Langkah-langkah kegiatan dalam analisis konjoin mengikuti prosedur yang diungkapkan oleh Supranto (2004) sebagaimana tampak pada ilustrasi Gambar 1 di bawah ini.

\begin{tabular}{|c|c|c|}
\hline \multirow{4}{*}{ Tahap 1} & \multicolumn{2}{|c|}{ Perumusan Masalah } \\
\hline & Metode & Angket, wawancara, dan diskusi (Rosada, 2002) \\
\hline & Peserta & Para pakar berpengalaman \\
\hline & Tujuan & $\begin{array}{l}\text { Melakukan identifikasi atribut dengan taraf/level masing- } \\
\text { masing dan dihasilkan } 5 \text { atribut, yang masing-masing } \\
\text { memiliki } 2 \text { taraf. }\end{array}$ \\
\hline \multirow{4}{*}{ Tahap 2} & \multicolumn{2}{|c|}{ Merancang kombinasi atribut (kartu profil) } \\
\hline & Metode & $\begin{array}{l}\text { Kartu profil menggunakan desain profil penuh (full-profile), } \\
\text { lalu direduksi dengan cara orthogonal array melalui } \\
\text { perangkat lunak SPSS (Ghozali, 2006) }\end{array}$ \\
\hline & Peserta & Peneliti \\
\hline & Tujuan & $\begin{array}{l}\text { Merancang kombinasi atribut (kartu profil) ke dalam bentuk } \\
\text { angket lanjutan. }\end{array}$ \\
\hline \multirow{4}{*}{ Tahap 3} & \multicolumn{2}{|c|}{ Penyebaran angket lanjutan } \\
\hline & Metode & $\begin{array}{l}\text { Survei dengan dalam bentuk Microsoft Forms dapat diakses } \\
\text { dari tautan www.bit.ly/dosen-idaman yang dibagikan melalui } \\
\text { pesan instan Whatsapp. }\end{array}$ \\
\hline & Peserta & Mahasiswa sebagai responden \\
\hline & Tujuan & $\begin{array}{l}\text { Mengumpulkan data primer dari para responden dengan cara } \\
\text { menuliskan peringkat (ranking) terhadap kartu profil yang } \\
\text { telah dibagikan (Kembaren, Bangun, \& Sitepu, 2014) }\end{array}$ \\
\hline & & $\lcm{15}$ \\
\hline \multirow[b]{3}{*}{ Tahap 4} & \multicolumn{2}{|c|}{ Analisis Data } \\
\hline & Metode & Analisis konjoin dengan SPSS. \\
\hline & Tujuan & $\begin{array}{l}\text { Perhitungan nilai kepentingan, tingkat kegunaan, dan } \\
\text { pengukuran korelasi serta keakuratan (Gustafsson, Herrmann, } \\
\text { \& Huber, 2007; Hair, Black, Babin, Anderson, \& L.T, 2021; } \\
\text { Johnson \& Wichern, 2000). }\end{array}$ \\
\hline \multirow[b]{3}{*}{ Tahap 5} & \multicolumn{2}{|c|}{ Hasil dan kesimpulan } \\
\hline & Metode & Penyajian data dan pelaporan \\
\hline & Tujuan & $\begin{array}{l}\text { Mengetahui persepsi dari ciri-ciri dosen yang diinginkan dan } \\
\text { diutamakan oleh mahasiswa (Hair et al., 2021) } \\
\text { Memberikan rekomendasi kepada pimpinan }\end{array}$ \\
\hline
\end{tabular}




\section{Gambar 1. Diagram alur tahapan analisis konjoin}

\section{Hasil}

Ada banyak atribut yang menjadi daya tarik mahasiswa terhadap dosennya. Melalui diskusi dan wawancara dengan pakar, peneliti memilih lima atribut terbanyak yang dituliskan oleh tim dosen berpengalaman. Atribut tersebut menggambarkan variabel yang menjadi daya tarik mahasiswa untuk mengikuti perkuliahan di PTS. Kelima atribut tersebut kemudian disusun dalam angket lanjutan. Adapun kelima atribut tersebut, yaitu intensitas umpan balik yang diberikan dosen, metode pembelajaran yang diterapkan oleh dosen sewaktu perkuliahan, penguasaan materi, kedisiplinan dosen, dan sikap dosen terhadap mahasiswa. Masing-masing atribut memiliki dua taraf yang berbeda. Atribut intensitas umpan balik mempunyai taraf selalu dan kadang-kadang, metode pembelajaran memiliki taraf mutakhir dan konvensional, atribut penguasaan materi memiliki taraf aplikatif dan teoretis, kedisiplinan memiliki taraf fleksibel dan tinggi, sedangkan sikap dosen dengan mahasiswa memiliki taraf wajar dan terbuka.

Melalui desain profil penuh,, kemudian direduksi dengan cara orthogonal array terbentuk kartu profil yang tersusun dalam angket lanjutan. Dari angket lanjutan ini tersusun dari 8 kartu yang berisi ciri-ciri profil dosen. Adapun desain angket lanjutan dapat diakses dari tautan www.bit.ly/dosenidaman. Melalui akses ini, data responden terkumpul.

Siapa sajakah respondennya? Dengan melihat deskripsi datanya akan terlihat dengan jelas identitas respondennya. Berdasarkan gendernya, responden terdiri dari 184 mahasiswi dan 86 mahasiswa. Apabila responden dinyatakan dalam persentasenya maka responden terdiri atas $31,85 \%$ mahasiswa dan 68,15\% mahasiswi yang tersaji dalam Gambar 2A di bawah ini.

A

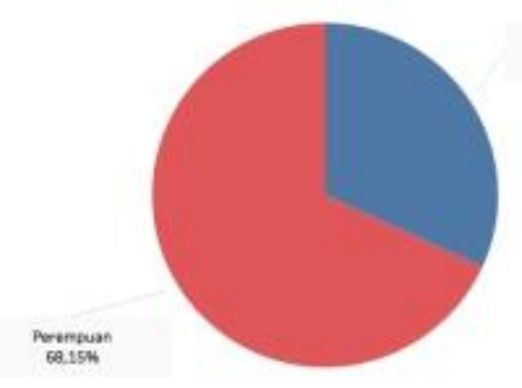

B

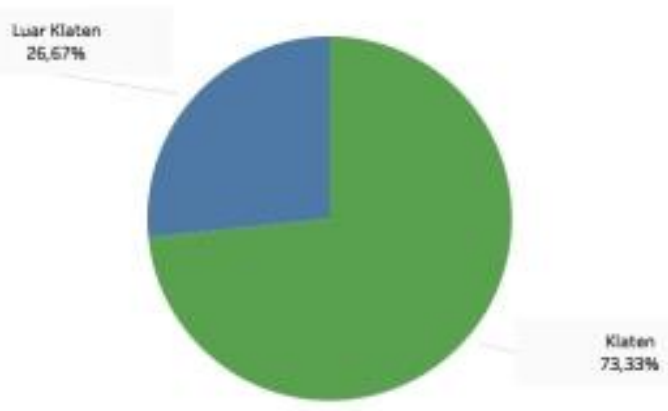

\section{Gambar 2. Deskripsi data responden menurut jenis kelamin (A) dan asal daerah (B)}

Apabila dilihat berdasarkan asal daerahnya, responden sebagian besar berasal dari wilayah sekitar Klaten, Jawa Tengah. Hanya sebagian kecil responden berasal dari luar Jawa Tengah. Menurut asal responden, peneliti membedakan identitas responden dalam dua kategori, yaitu wilayah Klaten dan luar Klaten. Berdasarkan identitas asalnya, responden terdiri dari 198 mahasiswa yang berasal dari daerah sekitar Klaten dan 72 mahasiswa berasal dari luar Klaten. Hasilnya dapat dilihat pada Gambar 2B di atas.

Banyaknya responden berdasarkan angkatan atau tahun masuk mahasiswa yaitu sebanyak 82 mahasiswa semester 3, sebanyak 93 mahasiswa semester 5, sebanyak 50 mahasiswa semester 7, dan 
sisanya 45 mahasiswa semester 9 seperti pada terlihat pada Gambar 3A. Namun, apabila ditinjau dari Indeks Prestasi Kumulatif (IPK), sebagian besar responden memiliki IPK sama dengan atau lebih besar 3,0 sebanyak 244 mahasiswa, sisanya 26 mahasiswa memiliki IPK tidak lebih dari 3,0. Persentase mahasiswa yang mempunyai IPK di atas 3 sebesar 90,37\% dan hanya 9,63\% mahasiswa mempunyai IPK di bawah 3,0.

A

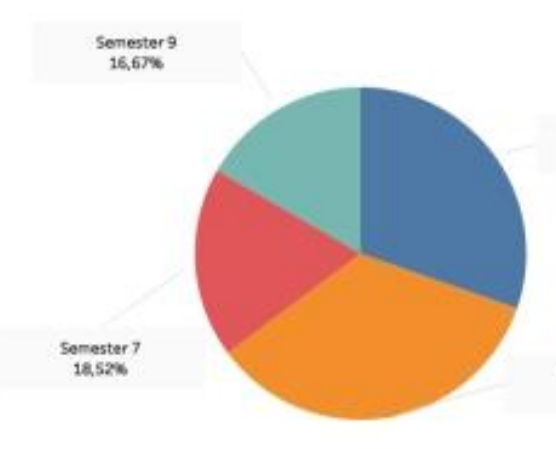

B

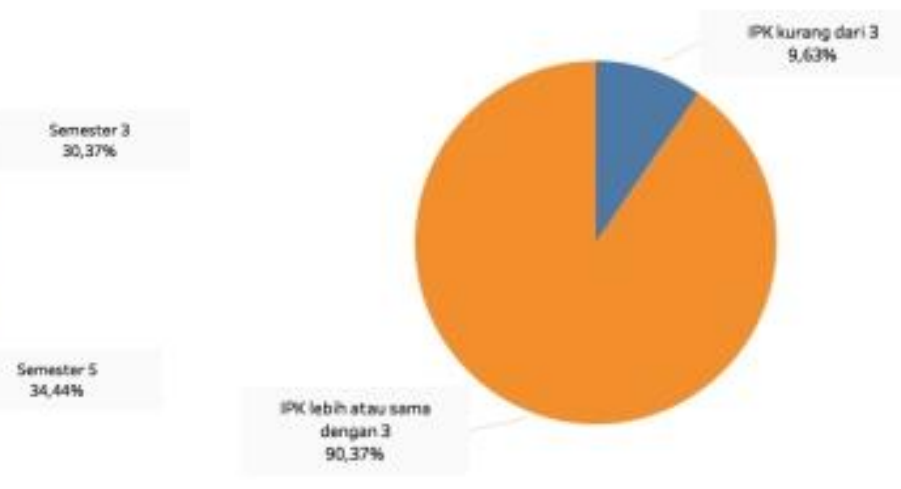

Gambar 3. Deskripsi data responden berdasarkan tahun masuk (A) dan indeks prestasi kumulatif (B )

Data yang digunakan untuk analisis konjoin diperoleh dari urutan kartu profil dalam angket lanjutan. Dalam penelitian ini, metode penelitian yang digunakan merupakan statistika nonparametrik yang menggunakan skala ordinal, yaitu data berupa rangking.

Hasil perhitungan analisis konjoin dapat dilihat secara keseluruhan atau agregat. Hasil analisis ini menunjukkan suatu gabungan dari pendapat seluruh responden penelitian. Perhitungan nilai kepentingan secara agregat dapat terlihat dalam Tabel 1 berikut ini.

Tabel 1. Nilai kepentingan atribut secara agregat

\begin{tabular}{lccccc}
\hline \multicolumn{1}{c}{ Atribut } & $\begin{array}{c}\text { Umpan } \\
\text { balik }\end{array}$ & $\begin{array}{c}\text { Metode } \\
\text { pembelajaran }\end{array}$ & $\begin{array}{c}\text { Penguasaan } \\
\text { materi }\end{array}$ & Disiplin & Sikap \\
\hline $\begin{array}{l}\text { Nilai } \\
\text { kepentingan }\end{array}$ & 11.272 & 52.582 & 8.674 & 13.331 & 14.141 \\
\hline
\end{tabular}

Berdasarkan nilai kepentingan pada masing-masing atribut di atas, atribut metode pembelajaran mempunyai nilai kepentingan yang paling besar. Kemudian diikuti oleh atribut sikap dosen, kedisiplinan dosen, intensitas umpan balik, dan yang paling kecil nilainya merupakan atribut penguasaan materi. Dengan demikian, urut-urutan atribut yang dianggap penting oleh mahasiswa adalah metode pembelajaran, sikap dosen terhadap mahasiswa, tingkat kedisiplinan dosen, intensitas umpan balik, dan penguasaan materi. Metode pembelajaran dianggap paling penting dibandingkan oleh atribut yang lainnya. Pada urutan kedua, atribut sikap dosen terhadap mahasiswanya, kemudian diikuti atribut disiplin, umpan balik, dan penguasaan materi. 
Pada masing-masing atribut mempunyai 2 taraf yang berbeda. Untuk mengetahui manakah taraf yang lebih diminati tiap atribut oleh mahasiswa maka peneliti membandingkan nilai kegunaan atribut pada masing-masing tarafnya. Adapun nilai kegunaannya terlihat dalam Tabel 2 berikut.

Tabel 2. Nilai kegunaan atribut secara agregat

\begin{tabular}{llcclc}
\hline \multicolumn{1}{c}{ Atribut } & \multicolumn{1}{c}{ Taraf } & $\begin{array}{c}\text { Nilai } \\
\text { Kegunaan }\end{array}$ & Atribut & Taraf & $\begin{array}{c}\text { Nilai } \\
\text { Kegunaan }\end{array}$ \\
\hline Umpan balik & Selalu & 0.309 & Displin & Fleksibel & 0.366 \\
& Kadang-kadang & -0.309 & & Tinggi & -0.366 \\
Metode & Mutakhir & 1.443 & Sikap & Terbuka & -0.388 \\
pembelajaran & Konvensional & -1.443 & & Wajar & 0.388 \\
Penguasaan & Aplikatif & 0.238 & & & \\
materi & Teoritis & -0.238 & (Konstan) & & 4.500 \\
\hline
\end{tabular}

Berdasarkan nilai kepentingan dalam Tabel 1 dan nilai kegunaan dalam Tabel 2 di atas, atribut metode pembelajaran mempunyai nilai kepentingan yang paling besar dibandingkan dengan nilai kepentingan pada atribut-atribut lainnya. Oleh karena itu, atribut metode pembelajaran menjadi atribut yang paling dipertimbangkan pertama kali oleh mahasiswa. Atribut metode pembelajaran memiliki dua taraf atribut, yaitu metode pembelajaran yang mutakhir dan metode pembelajaran yang konvensional. Nilai kegunaan pada atribut metode pembelajaran mutakhir lebih besar daripada konvensional. Hal ini menggambarkan bahwa mahasiswa lebih menyukai kepada dosen yang perkuliahannya menggunkaan metode pembelajaran yang mutakhir daripada dosen yang mempertahankan metode pembelajaran konvensional.

Nilai kegunaan maupun nilai kepentingan pada atribut sikap dosen terhadap mahasiswa berada pada urutan terbesar kedua. Hal ini berarti sikap dosen terhadap mahasiswa menjadi segmentasi yang kedua setelah adanya atribut metode pembelajaran. Pada atribut sikap dosen terhadap mahasiswa mempunyai dua taraf yang berbeda, yaitu sikap terbuka dan sikap wajar. Nilai kegunaan dari kedua taraf ini sama, yaitu 0,388. Akan tetapi, karena pada taraf atribut sikap wajar bernilai positif, sedangkan tanda negatif pada sikap terbuka yang artinya bahwa mahasiswa lebih menyukai kepada dosen yang bersikap wajar terhadap mahasiswa atau tidak berlebihan.

Nilai kegunaan maupun nilai kepentingan pada atribut tingkat kedisiplinan dosen berada pada urutan ketiga. Nilai kegunaan atribut sikap dosen terhadap mahasiswa sangat kecil selisihnya dengan nilai kegunaan pada atribut kedisiplinan dosen. Hal ini berarti kedisiplinan dosen menjadi segmentasi yang ketiga setelah atribut metode dan sikap. Pada atribut ini mempunyai dua taraf yaitu kedisiplinan yang fleksibel serta kedisiplinan yang tinggi. Nilai kegunaan dari kedua taraf ini besarnya sama, yaitu 0,366. Karena pada taraf atribut kedisiplinan yang fleksibel bernilai positif, sedangkan tanda negatif pada disiplin yang tinggi maka mahasiswa lebih menyukai dosen yang memiliki kedisiplinan yang fleksibel daripada dosen yang sangat tinggi tingkat kedisiplinannya.

Nilai kegunaan maupun nilai kepentingan pada atribut umpan balik pada urutan keempat. Hal ini berarti intensitas umpan balik yang diberikan dosen menjadi segmentasi yang keempat setelah atribut metode pembelajaran, sikap dosen, dan kedisiplinan dosen. Pada atribut ini terdapat dua taraf 
yaitu umpan balik dengan intensitas sering dan umpan balik dengan intensitas kadang-kadang. Nilai kegunaan dari kedua taraf ini sama, yaitu 0,309. Karena pada taraf atribut umpan balik dengan intensitas sering/selalu, sedangkan tanda negatif pada atribut umpan balik dengan intensitas kadangkadang maka mahasiswa lebih menyukai dosen yang sering memberikan umpan balik kepada mahasiswa.

Di pihak lain, nilai kepentingan pada atribut penguasaan materi mempunyai nilai yang paling kecil. Hasil hitung ini berarti bahwa atribut penguasaan materi menjadi segmentasi urutan terakhir setelah atribut metode pembelajaran, sikap dosen, kedisiplinan dosen, dan umpan balik. Pada atribut ini terdapat dua taraf yaitu penguasaan materi secara aplikatif dan penguasaan materi secara teoretis. Nilai kegunaan dari kedua taraf ini besarnya sama, yaitu 0,238. Akan tetapi, pada taraf atribut penguasaan materi untuk taraf aplikatif bernilai positif, sedangkan tanda negatif pada atribut penguasaan materi secara teoretis, yang berarti bahwa mahasiswa lebih menyukai kepada dosen yang mampu menguasai materi secara aplikatif, bukan hanya sekedar teoretis-teoretis.

Peneliti menggunakan uji korelasi Pearson's dan korelasi Kendall's untuk melihat seberapa kuat hubungan perkiraan dengan fakta. Pengukuran korelasi menggunakan uji Pearson's sebesar 0,969, sedangkan menggunakan uji Kendall'sebesar 0,929. Ukuran kepercayaan hasil dari perhitungan analisis konjoin ini reratanya lebih dari $90 \%$. Korelasi ini tergolong kuat disebabkan nilainya tidak lebih kecil dari 0,5 (Supandi, 2012). Hal ini menggambarkan terdapatnya hubungan yang kuat antara dugaan dengan fakta, atau berarti bahwa prediksi dengan kenyataannya mempunyai keakuratan (validitas) yang tinggi pada proses konjoin. Adapun pada uji signifikansi korelasi dari delapan kartu profil menghasilkan signifikansi 0,001 (kurang dari 0,05). Keadaan ini menunjukkan bahwa kedelapan korelasi dari kartu profil tersebut memiliki signifikansi yang sangat kuat.

\section{Pembahasan}

Atribut-atribut dalam penelitian ini akan menjadi pemicu motivasi mahasiswa untuk mengikuti perkuliahan. Atribut umpan balik, metode pembelajaran, penguasaan materi, kedisplinanan, dan sikap dosen terhadap mahasiswa dapat memicu motivasi mahasiswa dalam mengikuti perkuliahan. Mahasiswa yang memiliki motivasi tinggi akan cenderung menyusun perencanaan pembelajaran yang baik (Çam \& Ünal Oruç, 2014). Motivasi belajar mahasiswa tidak sepenuhnya bergantung pada karakteristik dosen sewaktu mengajar, melainkan bergantung pula pada keadaan lingkungan fisik seperti desain ruangan, fasilitas, serta kenyamanan kelas (Greiff, Holt, \& Funke, 2013; Hopkins, Tate, Sylvester, \& Johnstone, 2016; Setioningtyas \& Widyatmika, 2017). Seorang dosen diharapkan mampu memberikan motivasi yang tinggi terhadap mahasiswa melalui komunikasi terbuka, kesantunan dalam berpakaian, proses belajar secara tim, kepemimpinan, dan kepedulian sosial (Erozkan, 2013; Merdian \& Warrior, 2015; Nastiti, 2015; Setiawan, 2010).

Agar dapat memberikan motivasi seperti yang diutarakan oleh peneliti di atas, dosen wajib memiliki perilaku profesionalisme yang diharapkan oleh Negara untuk kemajuan pendidikan di Indonesia. Profesionalisme kinerja dosen terlihat dari empat kompetensi yang wajib dimiliki oleh dosen (Sufianti, 2015). Keempat kompetensi tersebut meliputi keahlian pedagogik, keahlian kepribadian, keahlian profesional, dan keahlian sosial. Menurut (Hasanati, 2017), apabila empat kompetensi yang dimiliki oleh dosen ini cenderung semakin baik, maka akan semakin baik pula komitmen kinerja dosen. Sejalan dengan hasil penelitian Hasanati tersebut, semua atribut dalam 
penelitian ini, yaitu umpan balik, metode pembelajaran, penguasaan materi, kedisplinan, dan sikap menggambarkan dari empat kompetensi tersebut.

Kelima atribut dalam penelitian ini mewakili empat kompetensi. Pada atribut umpan balik dan penguasaan materi mewakili kompetensi profesional, atribut metode pembelajaran mewakili kompetensi pedagogik, atribut displin mewakili kompetensi kepribadian, sedangkan atribut sikap dosen terhadap mahasiswa mewakili kompetensi sosial.

Urutan atribut manakah yang lebih diutamakan oleh responden, maka peneliti membandingkan nilai kepentingan dari kelima atribut tersebut. Menurut pengukuran tingkat kepentingan atribut secara agregat ini menggambarkan bahwa atribut yang menjadi segmentasi pertama oleh responden yaitu atribut metode pembelajaran dengan nilai kepentingannya sebesar 52,582\%. Atribut yang dipersepsikan penting oleh mahasiswa pada urutan kedua yaitu atribut sikap dosen dengan nilai kepentingannya sebesar $14,141 \%$. Segmentasi pada urutan ketiga adalah atribut kedisiplinan dosen dengan nilai kepentingannya sebesar $13,331 \%$. Atribut yang menjadi segmentasi pada urutan keempat yaitu intensitas pemberian umpan balik dengan nilai kepentingannya sebesar 11,271\%. Pada atribut penguasaan materi dengan nilai kepentingannya paling kecil, yaitu sebesar 8,674\% sehingga segmentasi pada atribut penguasaan materi berada pada urutan terakhir. Semua atribut tersebut menjadi faktor yang penting dalam mempengaruhi aktivitas mahasiswa di kampus, semangat belajar mahasiswa, motivasi mahasiswa untuk menyelesaikan perkuliahan, dan dukungan mahasiswa dalam memajukan semua program studi. Setelah dilakukan analisis konjoin, dihasilkan kombinasi sifat-sifat profil dosen yang dipertimbangkan atau disukai oleh mahasiswa. Ciri-ciri dosen ini dapat ditentukan dari besarnya masing-masing nilai kegunaan yang bernilai positif. Kombinasi ciri-ciri dosen yang menjadi preferensi mahasiswa, yaitu dosen menerapkan metode pembelajaran yang mutakhir, sikap dosen terhadap mahasiswa yang wajar, dosen yang memiliki displin yang fleksibel, dosen yang selalu memberikan umpan balik, dan dosen menguasai materi seara aplikatif.

Metode pembelajaran yang diterapkan oleh dosen dalam perkuliahan menjadi atribut paling penting bagi mahasiswa. Penerapan metode pembelajaran menyiratkan kompetensi pedagogik yang dimiliki oleh dosen. Responden dari semua program studi mengedapankan atribut ini. Ada dua kategori metode pembelajaran yang diteliti dalam penelitian ini, yaitu metode pembelajaran yang konvensional dan metode pembelajaran yang mutakhir. Sebagian dosen masih bersifat konvensional, namun sudah banyak pula dosen memanfaatkan kemajuan teknologi seperti handphone dan internet dalam pembelajaran. Bagi mahasiswa, metode perkuliahan berpengaruh terhadap prestasi belajarnya. Hal ini sejalan dengan penelitian yang telah dilakukan beberapa peneliti seperti Sahid, 2007; Yuliana dan Firmansah, 2018; Yuliana, Tasari, \& Wijayanti, 2017. Ketiga penelitian tersebut juga mengungkapkan bahwa metode pembelajaran yang inovatif, interaktif, dan mutakhir lebih efektif daripada metode pembelajaran konvensional. Hal ini sangatlah wajar, apabila mahasiswa lebih tertarik dengan model pembelajaran yang mengedepankan kemajuan teknologi seperti pembelajaran menggunakan mobile learning (Nawi, Hamzah, Ren, \& Tamuri, 2015; Sulisworo, Kartika, \& Firdausy, 2014) karena lebih interaktif dan tidak membosankan.

Pada urutan kedua, sikap dosen ternyata juga menjadi daya tarik bagi mahasiswa. Sikap dosen yang baik dapat terlihat dari interaksi dosen terhadap mahasiswanya, baik di dalam kelas maupun di luar kelas, baik secara visual maupun melalui media sosial. Interaksi aktif di luar kelas antara dosen dan mahasiswa mendorong dosen untuk mengenal kepribadian mahasiswa dan mendorong mahasiswa untuk memajukan program studi yang ada di Perguruan Tinggi. Interaksi dan hubungan 
secara personal yang baik antara mahasiswa dengan dosennya akan memiliki manfaat jangka panjang, seperti menumbuhkan semangat untuk menghargai perbedaan-perbedaan, menumbuhkan kemampuan kognitif, afektif serta budaya, dan menumbuhkan kemampuan bekerja sama, berpikir kreatif dalam menyelesaikan permasalahan di antara mahasiswa juga dalam masyarakat (Boumová, 2008; Nyadanu, Garglo, Adampah, \& Garglo, 2014; Ryser, Halseth, \& Thien, 2009; Suwarni, 2012). Sikap dan interaksi ini menunjukkan kompetensi sosial yang wajib dimiliki oleh dosen. Sikap dosen terhadap mahasiswa dalam penelitian ini dikelompokkan menjadi sikap yang wajar dan sikap terbuka. Sikap wajar dan terbuka merupakan sikap rasa keingintahuan dosen terhadap kondisi mahasiswa. Batas sikap keingintahuan yang wajar, seperti terlihat dari rasa keingintahuan dosen terhadap studi mahasiswa, sedangkan sikap terbuka merupakan rasa keingintahuan dosen yang berlebihan terhadap mahasiswa, seperti rasa ingin tahu dosen terhadap masalah pribadi dan keluarga mahasiswa. Menurut hasil penelitian ini, sikap yang cukup wajar dari dosen lebih dikehendaki oleh mahasiswa. Hal ini bisa terlihat dari nilai kegunaannya. Nilai kegunaan dari taraf sikap wajar dosen bernilai positif, sedangkan sikap terbuka bernilai negatif.

Atribut berikutnya, adalah atribut kedisiplinan. Kedisiplinan mencerminkan kompetensi kepribadian dosen yang perlu dimiliki oleh dosen. Melalui kompetensi ini, dosen dapat memberikan keteladanan etika dan penanaman kesadaran moral (Astuti, 2014; Nastiti, 2015; Setiawan, 2010). Keteladanan sikap displin dapat memberikan pengaruh kedisplinan mahasiswa dalam kehidupan sehari-hari, yang ternyata dapat berimbas pada hasil belajar mahasiswa (Nurfitriyani, 2015). Etika kedisiplinan seorang dosen dapat dilihat seperti dari kehadiran dalam mengajar yang tepat waktu, pengumpulan tugas-tugas perkuliahan, dan kejujuran dalam pelaksanaan ujian. Kedisplinan ini mengandung konsekuensi yang tinggi dari dosen dengan mahasiswa. Menurut hasil penelitian ini, atribut sikap displin berada pada urutan ketiga yang dipertimbangkan oleh dosen. Sebagian dosen memiliki kedisiplinan yang sangat tinggi, sebagian lagi bersikap seperlunya atau fleksibel. Dosen yang memiliki disiplin yang fleksibel justru lebih disukai oleh mahasiswanya, daripada dosen yang sangat tinggi tingkat kedisiplinannya. Hal ini dapat dilihat dari nilai kegunaannya. Atribut kedisiplinan dosen pada taraf fleksibel bernilai positif, sedangkan pada taraf displin sangat tinggi bernilai negatif.

Pada urutan berikutnya, kompetensi profesional menjadi atribut yang dipertimbangkan terakhir oleh mahasiswa. Sikap profesional dosen terlihat dari penguasaan materi dan pemberian umpan balik. Diantara dua sikap ini, atribut umpan balik lebih dipertimbangkan daripada atribut penguasaan materi.

Setelah pembelajaran ataupun pada akhir pembelajaran, pada umumnya dosen memberikan umpan balik seperti latihan, tugas, dan ujian. Umpan balik ini kemudian direspon oleh dosen yang bersangkutan untuk ditindaklanjuti, dibahas bersama-sama dengan mahasiswa, bahkan disebarluaskan hasilnya kepada mahasiswa. Intensitas pemberian umpan balik ternyata menjadi daya tarik mahasiswa untuk mengikuti perkuliahan. Bahkan, pemberian umpan balik ternyata menjadi indikator seorang dosen memiliki kemampuan pedagogik yang baik (Nur'aeni, 2011). Akan tetapi, tidak semua dosen selalu memberikan umpan balik. Intensitas pemberian dosen satu dengan dosen yang lain tidaklah sama. Sebagian dosen selalu memberikan umpan balik, sedangkan sebagian lagi hanya kadangkala memberikan umpan balik. Menurut penelitian ini, nilai kegunaan pada taraf dosen yang selalu memberikan umpan balik bernilai positif, sedangkan dosen yang kadang-kadang memberikan umpan balik bernilai negatif. Hal ini dapat memberikan kesimpulan bahwa intensitas umpan balik dengan frekuensi yang cukup sering dan kontinu ternyata lebih 
disukai oleh mahasiswa. Pernyatan ini selaras dengan riset yang menggambarkan bahwa pemberian umpan balik dapat mempengaruhi prestasi belajar (Rahayu, 2016).

Penguasaan materi menjadi atribut urutan terakhir yang dipentingkan oleh mahasiswa. Tak sebatas teori-teori saja, ternyata dosen mempunyai kemampuan untuk mengaplikasikan teori-teori yang dimilikinya. Mahasiswa berharap kepada dosen agar aplikatif dari ilmunya tersebut dapat ditularkan kepadanya. Menurut hasil penelitian ini, mahasiswa cenderung lebih menyukai kepada dosen yang mampu menguasai perkuliahan secara aplikatif. Dengan penguasaan materi secara aplikatif ini dapat mendorong dosen untuk menghasilkan produk pembelajaran (Hasana \& Nursit, 2017), menyiapkan mahasiswa untuk mengetahui dunia di luar kampus, memberikan gambaran tentang dunia kerja, serta menambah semangat belajar. Kondisi ini menjadi sangat wajar, apabila atribut penguasaan materi menjadi atribut yang dipertimbangkan oleh mahasiswa.

Dari penelitian ini diperolehlah profil dosen yang dipertimbangkan oleh mahasiswa secara urut. Profil dan ciri-ciri dosen ini menjadi persepsi mahasiswa terhadap dosen harapannya. Pada akhirnya, dosen akan berusaha untuk mewujudkan keinginan mahasiswa mengenai ciri-ciri dosen harapannya karena dapat menambah semangat dan memotivasi belajarnya. Dari profil dosen harapannya ini pula, mahasiswa akan menyebarkan informasi kepada masyarakat bahwa di PTS ini memiliki dosen-dosen yang mengedepankan 4 kompetensi dan pelaksanaan perkuliahan yang sesuai harapan. Pada akhirnya, profil ini menjadi daya tarik bagi calon mahasiswa. Bagi perguruan tinggi, profil dosen seperti ini akan menjadi rekomendasi dan kebijakan yang dapat dilakukan sebagai usaha untuk menarik minat calon mahasiswa.

Dari penelitian ini, hanya ada lima variabel bebas yang diteliti. Padahal, masih banyak atribut lain juga dapat mempengaruhi ketertarikan mahasiswa terhadap profil dosen dalam mengajar. Sebagai saran untuk penelitian berikutnya, perlu diteliti atribut-atribut lainnya yang ikut mempengaruhi dosen dalam mengajar, khususnya keahlian-keahlian yang diperlukan pada masa Revolusi Industri 4.0 seperti penguasaan teknologi dan informasi. Tuntutan kecakapan yang harus dikuasai pada abad ke-21 seperti komunikasi, berpikir kritis, kolaborasi dan kreatif juga dapat dimanfaatkan sebagai kerangka riset dalam rangka asesmen kompetensi dosen. Pengembangan penelitian juga dapat dilakukan dengan memperbesar dan memperluas cakupan responden di beberapa Perguruan Tinggi, baik PTN maupun PTS.

\section{Kesimpulan}

Menurut penelitian ini didapatkan simpulan bahwa urut-urutan atribut yang menjadi pertimbangan mahasiswa untuk kuliah di PTS yaitu (1) metode pembelajaran, (2) sikap dosen terhadap mahasiswa, (3) tingkat kedisiplinan dosen, (4) intensitas umpan balik, dan (5) penguasaan materi. Dari keterangan ini memberikan arti bahwa sebagian besar mahasiswa beranggapan metode pembelajaran yang digunakan oleh dosen menjadi atribut paling dipentingkan dalam memotivasi belajar mahasiswa dibandingkan dengan atribut-atribut lainnya. Didasari analisis konjoin ini menunjukkan bahwa mahasiswa lebih menyukai dosen dengan pembelajaran mutakhir, memiliki kewajaran dalam bersikap terhadap mahasiswanya, memiliki tingkat kedisiplinannya fleksibel, selalu memberikan umpan balik, dan mampu menguasai materi secara aplikatif. Persepsi dari ciriciri dosen inilah yang diinginkan oleh mahasiswa sehingga dapat memberikan pengaruh untuk memotivasi semangat belajar mahasiswa. Tak hanya itu, ciri profil seperti inilah yang perlu dimiliki dan dipertimbangkan oleh pendidik agar menjadi daya tarik bagi calon mahasiswa untuk kuliah di PTS. 


\section{Ucapan Terimakasih}

Para penulis memberikan ucapan terima kasih kepada: (1) Pusat Penelitian, LPPM Universitas Widya Dharma atas pendanaan riset skema unggulan tahun 2018; (2) Pujo Darmo, Th. Kriswianti Nugrahaningsih, Gunawan Budi Santoso, Iswan Riyadi, dan Udiyono selaku tim pakar yang telah membantu dalam validasi angket pendahuluan; dan (3) Rizky Prasetya, Sutrisno, Endang Sulastri, Heru Purwanto, dan Eni Handayani dari BEM Universitas Widya Dharma Klaten yang telah berkontribusi pada penyebaran angket daring di kalangan mahasiswa dan tidak lupa kepada para mitra bestari yang sudah memberikan komentar konstruktif untuk tulisan ini.

\section{Referensi}

Astuti, P. (2014). Kontribusi Profesionalisme dan Keteladanan Dosen terhadap Nilai-Nilai Karakter Mahasiswa. Perspektif Ilmu Pendidikan, 28(2), 148. https://doi.org/10.21009/PIP.282.10

Boumová, B. V. (2008). Faculty of Arts Department of English and American Studies English Language and Literature Traditional vs Modern Teaching Methods: Advantages and Disadvantages of Each Master's Diploma Thesis.

Çam, S. S., \& Ünal Oruç, E. (2014). Learning Responsibility and Balance of Power. International Journal of Instruction, 7(1), 5-16. Retrieved from https://manchester.idm.oclc.org/login?url=http://search.proquest.com/docview/1871592565?a countid $=12253$

Enoh, M. (2006). Pengaruh Kepemimpinan Dosen, Kualitas Layanan Akademik, dan Kualitas Layanan Administratif terhadap Tingkat Kepuasan Mahasiswa. Jurnal Ilmu Pendidikan, 13(2), 113-121. https://doi.org/10.17977/jip.v13i2.54

Erozkan, A. (2013). The Effect of Communication Skills and Interpersonal Problem Solving Skills on Social Self-Efficacy. Educational Sciences: Theory and Practice, 13(2), 739-745.

Ghozali, I. (2006). Aplikasi Analisis Multivariate dengan Program SPSS. Semarang: Badan Universitas Diponegoro.

Greiff, S., Holt, D. V., \& Funke, J. (2013). Perspectives on Problem Solving in Educational Assessment: Analytical, Interactive, and Collaborative Problem Solving. The Journal of Problem Solving, 5(2). https://doi.org/10.7771/1932-6246.1153

Gustafsson, A., Herrmann, A., \& Huber, F. (2007). Conjoint Measurement Methods and Applications (4th ed.). Berlin: Springer-Verlag Berlin Heidelberg. https://doi.org/10.1007/978-3-540-71404-0

Hair, J. F., Black, W. C., Babin, B. J., Anderson, R. E., \& L.T, R. (2021). Multivariate Data Analysis Seventh Edition (7th ed.). New Jersey: Pearson Prentice Hall.

Hasana, S. N., \& Nursit, I. (2017). Pengembangan Multimedia Menggunakan Visual Basic For Application ( VBA ) untuk Meningkatkan Profesionalisme Guru Matematika. Seminar 
Nasional Matematika Dan Pendidikan Matematika UNY, 681-688.

Hasanati, N. (2017). Pengaruh Kompetensi terhadap Komitmen Profesi pada Dosen. ANALITIKA, 9(1), 1-16. https://doi.org/10.31289/ANALITIKA.V9I1.738

Hopkins, N., Tate, M., Sylvester, A., \& Johnstone, D. (2016). Motivations for 21st century school children to bring their own device to school. Information Systems Frontiers, 1-13. https://doi.org/10.1007/s10796-016-9644-z

Johnson, R. A., \& Wichern, D. W. (2000). Applied Multivariate Statistical Analysis. New Jersey: Prentice Hall.

Kembaren, S. C., Bangun, P., \& Sitepu, R. (2014). Preferensi Wisatawan Terhadap Kunjungan Wisata Pulau Samosir dengn Analisis Konjoin. Saintia Matematika, 2(3), 267-275.

Kottasz, R. (2005). Reasons for Student Non-Attendance at Lectures and Tutorials: An Analysis. Investigation's Jurnal in University Teaching and Learning, 2(2), 5-16.

Merdian, H. L., \& Warrior, J. K. (2015). Effective communication between students and lecturers: Improving student-led communication in educational settings. Psychology Teaching Review, 21(1), 25-38. Retrieved from http://ovidsp.ovid.com/ovidweb.cgi?T=JS\&PAGE=reference $\& D=$ psyc11\&NEWS=N\&AN=2 015-40359-004

Nastiti, U. D. (2015). Pengaruh layanan mengajar dosen dan pemanfaatan fasilitas belajar terhadap kepuasan mahasiswa di universitas pasundan. Jurnal Administrasi Pendidikan, 22(1), 1-13.

Nawi, A., Hamzah, M. I., Ren, C. C., \& Tamuri, A. H. (2015). Adoption of Mobile Technology for Teaching Preparation in Improving Teaching Quality of Teachers. International Journal of Instruction, 8(2), 113-124. https://doi.org/10.12973/iji.2015.829a

Nur'aeni, N. (2011). Pengaruh Motivasi, Kompetens,i dan Komitmen terhadap Kinerja Dosen Perguruan Tinggi Swasta di Kopertis Wilayah II Palembang (Survey pada Perguruan Tinggi Swasta di Kopertis Wilayah II Palembang). Jurnal Manajeman Dan Bisnis, 1(2), 101-129.

Nurfitriyani, M. (2015). Pengaruh Kreativitas dan Kedisiplinan Mahasiswa Terhadap Hasil Belajar Kalkulus. Formatif: Jurnal Ilmiah Pendidikan MIPA, 4(3), 219-226. https://doi.org/10.30998/formatif.v4i3.157

Nyadanu, S. D., Garglo, M. Y., Adampah, T., \& Garglo, R. L. (2014). The Impact of LecturerStudent Relationship on Self-Esteem and Academic Performance at Higher Education. Journal of Social Science Studies, 2(1), 264. https://doi.org/10.5296/jsss.v2i1.6772

Pujadi, A. (2007). Faktor-Faktor yang Mempengaruhi Motivasi Belajar Mahasiswa: Studi Kasus pada Fakultas Ekonomi Universitas Bunda Mulia. Business \& Management Journal Bunda Mulia, 3(2). https://doi.org/10.30813/bmj.v3i2.338

Rahayu, S. (2016). Pengaruh Pemberian Umpan Balik Terhadap Kesalahan Siswa Dalam 
Menyelesaikan Operasi Hitung Bentuk Aljabar. E-DuMath, 2(2), 218-123.

Rosada, R. (2002). Perbandingan Metode Pairwise Comparison dan Full profile dalam Pengumpulan Data untuk Analisis Konjoin. IPB Bogor.

Ryser, L., Halseth, G., \& Thien, D. (2009). Strategies and Intervening Factors Influencing Student Social Interaction and Experiential Learning in an Interdisciplinary Research Team. Research in Higher Education, 50(3), 248-267. https://doi.org/10.1007/s11162-008-9118-3

Sahid. (2007). Pengembangan Media Pembelajaran Berbasis ICT. Pendidikan Matematika FMIPA $U N Y, 1-16$.

Sahyar. (2009). Pengaruh Kompetensi Dosen dan Proses Pembelajaran terhadap Kepuasan Mahasiswa. Pekbis Jurnal, 1(3), 131-139.

Setianingtyas, A. F. (2012). Organisasi dan Eksistensinya Dalam Membentuk Pola Pikir Bagi Mahasiswa. Laporan Pengabdian Masyarakat Fakultas Psikologi. Universitas Widya Dharma Klaten. Universitas Widya DHarma.

Setiawan, R. (2010). Analisis Pengaruh Faktor Kemampuan Dosen , Motivasi Belajar Ekstrinsik dan Intrinsik Mahasiswa, Serta Lingkungan Belajar Terhadap Semangat Belajar. 1(2), 229243.

Setioningtyas, W. P., \& Widyatmika, S. W. (2017). Analisis Karakteristik Dosen yang Berpengaruh Terhadap Motivasi Belajar Mahasiswa pada Perguruan Tinggi Swasta di Kota Surabaya. Jurnal Studi Manajemen Dan Bisnis, 4(2), 277-287.

Sudiana, I. N. (2003). Peranan Profesionalisme Tenaga Pengajar (Dosen) terhadap Proses Pembelajaran di Perguruan Tinggi. Jurnal Pendidikan Dan Pengajaran, 36(4).

Sufianti, A. (2015). Pengaruh motivasi kerja dan kompetensi profesional terhadap kinerja dosen di sekolah tinggi pariwisata bandung. Administrasi Pendidikan, 22(1), 14-25.

Sulisworo, D., Kartika, I. J., \& Firdausy. (2014). Pengembangan Sistem Manajemen Pembelajaran Kooperatif Secara Mobile Berbasis Sistem Operasi Android. Indonesian Journal of Curriculum and Educational Technology Studies, 3(1), 56-62.

Supandi, E. D. (2012). Pendekatan Conjoint Analysis untuk Mengukur Tingkat Preferensi Mahasiswa terhadap Layanan Sistem Informasi Akademik di UIN Yogyakarta. Jurnal Fourier, 1(1), 1-9. https://doi.org/10.14421/fourier.2012.11.1-9

Supranto, J. (2004). Analisis Multivariat: Arti dan Interpretasi. Jakarta: Rineka Cipta.

Sutriningsih, N. (2016). Persepsi Mahasiswa tentang Kompetensi Mengajar Dosen Pengampu pada Mata Kuliah Struktur Aljabar. JURNAL E-DuMath, 2(1), 52-58.

Suwarni, E. (2012). Hubungan Gaya Mengajar Dosen dalam Proses Pembelajaran dengan Motivasi Belajar Mahasiswa Fakultas Psikologi dan Pendidikan Universitas Al Azhar Indonesia. Jurnal 
Al-Azhar Indonesia Seri Humaniora, 1(4), 246-256.

Wibisono, D. (2003). Riset Bisnis. Jakarta: Gramedia Pustaka Utama.

Yuliana, \& Firmansah, F. (2018). The Effectiveness of Problem-Based Learning With Social Media Assistance to Improve Students ' Understanding Toward Statistics. Infinity Journal of Mathematics Education, 7(2), 97-108. https://doi.org/10.22460/infinity.v7i2.p97-108

Yuliana, Tasari, \& Wijayanti, S. (2017). The Effectiveness of Guided Discovery Learning to Teach Integral Calculus for the Mathematics Students of Mathematics Education Widya Dharma University. Infinity Journal of Mathematics Education, 6(1), 1-10. https://doi.org/10.22460/infinity.v6i1.222 